\title{
Argonne $\mathbf{n}$
}

\section{Performance Validation of Advanced PHEV Vehicle}

Final CRADA Report

\author{
Energy Systems Division
}




\section{About Argonne National Laboratory}

Argonne is a U.S. Department of Energy laboratory managed by UChicago Argonne, LLC under contract DE-AC02-06CH11357. The Laboratory's main facility is outside Chicago, at 9700 South Cass Avenue, Argonne, Illinois 60439. For information about Argonne

and its pioneering science and technology programs, see www.anl.gov.

\section{DOCUMENT AVAILABILITY}

Online Access: U.S. Department of Energy (DOE) reports produced after 1991 and a growing number of pre-1991 documents are available free via DOE's SciTech Connect (http://www.osti.gov/scitech/)

Reports not in digital format may be purchased by the public from the National Technical Information Service (NTIS):

U.S. Department of Commerce

National Technical Information Service

5301 Shawnee Rd

Alexandria, VA 22312

www.ntis.gov

Phone: (800) 553-NTIS (6847) or (703) 605-6000

Fax: (703) 605-6900

Email: orders@ntis.gov

Reports not in digital format are available to DOE and DOE contractors from the

Office of Scientific and Technical Information (OSTI):

U.S. Department of Energy

Office of Scientific and Technical Information

P.O. Box 62

Oak Ridge, TN 37831-0062

www.osti.gov

Phone: (865) 576-8401

Fax: (865) 576-5728

Email: reports@osti.gov

Disclaimer

This report was prepared as an account of work sponsored by an agency of the United States Government. Neither the United States Government nor any agency thereof, nor UChicago Argonne, LLC, nor any of their employees or officers, makes any warranty, express or implied, or assumes any legal liability or responsibility for the accuracy, completeness, or usefulness of any information, apparatus, product, or process disclosed, or represents that its use would not infringe privately owned rights. Reference herein to any specific commercial product, process, or service by trade name, trademark, manufacturer, or otherwise, does not necessarily constitute or imply its endorsement, recommendation, or favoring by the United States Government or any agency thereof. The views and opinions of document authors expressed herein do not necessarily state or reflect those of the United States Government or any agency thereof, Argonne National Laboratory, or UChicago Argonne, LLC. 


\section{Performance Validation of Advanced PHEV Vehicle}

\section{Final CRADA Report}

prepared by

Michael Duoba

Energy Systems Division, Argonne National Laboratory

Participants: Ford Motor Company

$12 / 21 / 2016$ 
This page intentionally left blank 
Date:

$\underline{12 / 21 / 2016}$

CRADA Number:

$\underline{\text { ANL/ES-C0900401 }}$

CRADA Title:

Performance Validation of Advanced PHEV Vehicle

CRADA Start/End Date: 6/17/2009 to $\underline{6 / 17 / 2011}$

Argonne Dollars: $\quad \$ \underline{300,000}$

Participant Dollars: $\quad \$ \underline{18,000}$ (est)

Argonne PI:

Michael Duoba

Participant(s):

Ford Motor Company

Name

$\$ 18,000$ (est)

Participant Dollars

Research and Innovation Center, 2101 Village Road, MD 2149, Room 3150, Dearborn, MI 48121

Complete Address

$\begin{array}{ll}\text { N/A } & \$ \\ \text { Name } & \text { Participant Dollars }\end{array}$

Complete Address

N/A

Name

\$

Participant Dollars

Complete Address

DOE Program

Lee Slezak, Vehicle Technologies Program

Manager:

Summary of Major Accomplishments:

Ford developed a PHEV Escape as part of a DOE contract to develop a production-ready PHEV prototype. Although conventional certification tests were conducted by Ford during their development, Argonne was brought in at the half-way point and at end of the development project to run their researchoriented benchmark testing on one of their prototype vehicles in different states of controls development. Here are the accomplishments:

- Prototype vehicle was instrumented by installing voltage and current probes and a resolver was installed for engien speed and position.

- Other signals were collected such as several temperatures and sett up CAN network data collection. 
Summary of Major Accomplishments:

- 51 individual tests were conducted on the 4WD chassis dynamometer in December 2008, in both CD and CS modes over UDDS, US06, HWY, SC03 cycles, and research cycles including preformance and steady-state

- 66 individual tests were conducted run on the 4WD chassis dynamometer in Aug 2009, in both CD and CS modes over UDDS, US06, HWY, SC03 cycles, and research cycles including prefoemance and steady-state

- Data was analyzed and summarized for DOE in several in-person briefings. One briefing was held in early 2009 and another in the fall of 2009.

Summary of Technology Transfer Benefits to Industry:

Argonne's benchmark testing program is the perfect platform from which to leverage DOE research assets and institutional knowledge to evaluate the product of a substaintial DOE-funded project. Different control strategies were tested and evaluated in the context of new and complex testing methods that provide overall efficiency results. Testing methods and results were provided to both Ford and DOE.

Other Information/Results: (Papers, Inventions, Software, etc.)

The standard PHEV testing protocols (still in early use) were excersized for this testing program. The procedures worked well and did not fail to work as intended with the blended-type depleting control design. Without a real OEM-level test vehicle, many test procedure ideas and concepts could not be validated. These experiences went directly into SAE test standards that were chaired by Argonne staff. 
This page intentionally left blank 


\section{Argonne $\mathbf{A}$}

\section{Energy Systems Division}

Argonne National Laboratory

9700 South Cass Avenue, Bldg. \#

Argonne, IL 60439

www.anl.gov 
(2) 
Argonne National Laboratory is a U.S. Department of Energy

laboratory managed by UChicago Argonne, LLC 